Ю. О. Голоцукова

\title{
ПРО УНІВЕРСАЛЬНІ ТА СПЕЦИФІЧНІ РИСИ КАТЕГОРЇ̈ РЕЗУЛЬТАТИВА (НА МАТЕРІАЛ УКРАЇНСЬКОЇ ТА РОСІЙСЬКОЇ МОВ)
}

Голоцукова Ю. О. Про універсальні та специфічні риси категорії результатива (на матеріалі української та російської мов).

У статті проаналізовано та узагальнено погляди українських і зарубіжних лінгвістів щодо змісту понять «результатив», «статив», «пасив», «перфект»; досліджено кваліфікаційні та диференційні ознаки українських та російських результативних, стативних, пасивних, перфектних конструкцій; визначено особливості функціонування результативних конструкцій.

Ключові слова: результатив, статив, стан / дія, пасив, перфект.

Голоцукова Ю.А. Об универсальных и специфических чертах категории результатива (на материале украинского и русского языков).

В статье проанализированы и обобщены взгляды украинских и зарубежных лингвистов относительно содержания понятий «результатив», «статив», «пассив», «перфект»; исследованы квалификационные и дифференциальные признаки украинских и русских результативных, стативных, пассивных, перфектных конструкций; определены особенности функционирования результативных конструкций.

Ключевые слова: результатив, статив, состояние / действие, пассив, перфект.

Golotsukova Y. O. About the universal and specific lines of category of resultative (on material of the Ukrainian and Russian languages).

In the article are analyzed and summarized the views of Ukrainian and foreign linguists regarding the content of the concepts of "resultative", "stative", "passive", "perfect tense"; are investigated qualification and differential criteria of the Ukrainian and Russian resultative, stative, passive, perfect tense; are defined the peculiarities of resultative designs.

Key words: resultative, stative, state / action, passive, perfect tense.

○ Ю. О. Голоцукова, 2015. 
У мовознавстві кінця XX - початку XXI століття помітне місце посідають дослідження, присвячені результативним дієслівним конструкціям. Питаннями аналізу та класифікації результативних конструкцій у різних аспектах займалися такі лінгвісти, як Н. Авілова, О. Бондарко, Л. Буланін, В. Виноградов, І. Вихованець, М. Гловінська, К. Городенська, А. Загнітко, О. Ісаченко, Л. Коновалова, Ю. Князєв, Ю. Маслов, І І. Мучник, В. Недялков, В. Плунгян, Г. Сильницький, О. Холодович, М. Шелякін, С. Яхонтов та інші. Незважаючи на велику кількість праць, проблема результативності все ще залишається нерозв'язаною, оскільки на кожному новому етапі наукового пізнання постають нові питання, пов'язані 3 актуалізацією результативної семантики. Одним з таких є питання про універсальні та специфічні риси категорії результатива в українській та російській мовах. Цим зумовлюється актуальність пропонованого дослідження.

Мета дослідження - 3'ясування особливостей співвідношення результативів зі стативами, пасивами і перфектами, встановлення універсальних та специфічних рис категорії результатива в українській та російській мовах. Реалізація поставленої мети передбачає розв'язання таких завдань: проаналізувати погляди українських i зарубіжних лінгвістів щодо змісту понять «результатив», «статив», «пасив», «перфект»; встановити закономірності кореляції результатив/ статив / пасив / перфект в українській та російській мовах.

Термін «результатив» на сьогодні не має однозначного тлумачення, хоча вивченню цього поняття присвячено багато наукових праць. У спеціальній літературі мовознавці й саме поняття називають по-різному: I. Вихованець, А. Загнітко, В. Недялков, О. Холодович вживають термін «результатив», Л. Буланін - «пасив стану», «пасив», «статив», Л. Коновалова - «статальний пасив», Ю. Маслов - «перфект стану», «статальний перфект». На наш погляд, найдоречнішим терміном $є$ «результатив», оскільки саме цей термін більш «наочно» вказує на завершальний етап дії або послідовності дій, що привели до результативного стану. Терміном «результатив» називаємо предикативну форму, виражену пасивними дієприкметниками та акціональними предикативними формами на -но, -то від граничних і неграничних перфективів та імперфективів, яка позначає стан предмета, що передбачає попередню дію. Лінгвісти результатив зазвичай пов'язують із трьома явищами: стативом, пасивом, перфектом.

О. Холодович та його послідовники [3; 5] називають стативом предикативну форму, що позначає стан та якість предмета, тобто стативи 
- це конструкції з позначенням непроцесуальнї ознаки. Характерною рисою стативних конструкцій $\epsilon$ те, що вони надають об'єктові непроцесуальної ознаки, яка реалізується в конкретних ситуаціях, таких, як локалізований стан, зовнішній вигляд, внутрішня ознака і подібне. В українській та російській мовах стативне значення, як і результативне, виражається пасивними дієприкметниками та предикативними формами на -но, -то під впливом лексичного значення дієслова-мотиватора. Головна відмінність статива від результатива полягає в тому, що статив повідомляє лише про стан предмета, результатив - одночасно і про стан, $\mathrm{i}$ про попередню дію, результатом якої є цей стан. Тому статив може позначати, на відміну від результатива, природний первинний стан, що не виступає результатом якоїсь дії: укр. Ніхто не знав, куди иілити, бо острів той так заховано серед проток, дерев $і$ очеретів, щзо майже ніхто не відав про його існування (П. Загребельний) - острів заховано = острів заховався - природний стан; рос. Мы пошли на вал, возвышение, образованное природой и укрепленное частоколом (О. Пушкін) возвышение образованное $=$ возвышение образовалось (природний стан).

В українській та російській мовах стативне і результативне значення реалізуються в контексті. Наприклад, у реченні укр. Бабуся стояла, спершись на ціпок (така зігнута, зовсім переламана надвоє бабуся) (О. Донченко) лексема переламана, вжита у значенні «зігнута», позначає стан об'єкта бабуся, являє собою статив, оскільки характеризує об'єкт ознакою, яка не повідомляє про попередню дію, виконувану над ним, переламана надвоє бабуся - природний стан, що не є результатом попередньої дії. У реченні [Мати:]У тебе синяки під очима! [Гаврило:] Під очима то ще нічого, алибонь $i$ ребер скількохсь переламано (М. Кропивницький) лексема переламано являє собою результатив, оскільки стан об'єкта постає результатом свідомої дії чи діяльності суб'єкта, повідомляє про попередню дію «ламати», виконувану над ним.

У реченні рос. Лицо его, покрытое морщинами, оживлено было удивительною бодростию, глаза грозно сверкали из-под седых бровей (О. Пушкін) статив покрытое позначає природний стан об'єкта обличчя, характеризує його ознакою, яка не повідомляє про попередню дію, виконувану над ним. У реченні рос. Комната больше и выле моей, лучше меблирована, светлая; икаф, комод, диван и моя кровать, большая и широкая и покрытая зеленым шелковым стеганым одеялом (Ф. Достоєвський) лексема покрытая має результативне значення, оскільки позначає стан, який $\epsilon$ результатом свідомої діяльності: покривати $\rightarrow$ покрити $\rightarrow$ покрито (покритий).

๑ Ю. О. Голоцукова, 2015. 
Пасивом називають предикативну форму, що виражає стан предмета й позначає, що підмет речення не відповідає суб'єктові дії або що суб'єкт дії взагалі не виражений у реченні [3, с. 150]. В українській та російській мовах форми пасива $є$ омонімічними формам результатива. Частотними постають випадки, коли результатив і пасив припускають взаємозамінність у певних контекстах за незначної смислової зміни. Результативне значення має такі відмінні риси від пасивного значення:

а) ознака, яку виражає результатив, $\epsilon$ стійкою, тривалою. Показники тривалості визначають час результативного стану і тим самим свідчать про результативне значення лексеми. У реченні такий результатив виконує функцію присудка, тобто постає аналітичним дієсловом: укр. [Лючій (до християн):] Він, браття, ще не хрещений не сміс благословення вірним уділяти (Леся Українка); рос. Сознаюсь, что в порыве малодушия я проклинал шепотом медицину и свое заявление, поданное пять лет тому назад ректору университета (М. Булгаков) і таке інше. На відміну від російської мови, в українській мові показники тривалості також можуть позначати час самої дії. Це свідчить про пасивне значення дієприкметника: укр. Цілком зрозуміло, чому так швидко, заякийсь один рік після блокади, - позагоювані гарматні та бомбові рани на ленінградських будівлях (Остап Вишня) тощо. В російські мові такі конструкції репрезентують результативний стан: рос. Наш отпрыск, назад тому с полгода, обутый в штиблеты поиностранному и дрожа в ничем не подбитой шинелишке, воротился зимой в Россию из Швейцарии, где лечился от идиотизма (Ф. Достоєвський) і подібне;

б) результативне часове значення обмежене планом результату, «однопланове». Обмеженість результативного стану часовим планом допоміжного дієслова виявляється у сполученнях тих чи тих відповідних лексем зі словоформами, що містять вказівку на час. Минуле результатива в сполученні з показниками на зразок: укр. ще вчора, тільки-но, у той час, poc. еще вчера, в то время, только что і подібне передбачає, що в теперішньому часі цей стан вже завершився. Минуле пасива позначає відсутність цього стану та його настання. Порівняймо: укр.- Може, Іон уже $і$ підвищення мав, адже писав ще торік, що на сержанта був представлений... (М. Чабанівський). Конструкцію «ще торік був представлений» за результативного значення тлумачимо, як «торік був представлений i тільки-но 3 причини підвищення чи його скасування перестав бути представленим», за пасивного - «раніше не був представлений, і тільки торік його подали / представили на підвищення». 
Рос. »Должен! - возразил Савельич, час от часу приведенный в большее изумление, - да когда же, сударь, успел ты ему задолжать? (О. Пушкін) конструкція «час от часу приведенный» за результативного значення тлумачиться, як «Савич був збентежений колись, а зараз - ні», за пасивного - «Савич раніше не був збентежений, а наразі - став» і подібне;

в) момент появи стану (завершення дії) залишається, зазвичай, невизначеним. Наприклад: Укр. У 1141 році, коли Галицьке князівство було сформоване, більша частина Підкарпаття була приєднана до його володінь. За акціонального розуміння дієприкметника було сформоване аналітичного дієслова - можна витлумачити, що Галицьке князівство сформували саме у 1141 році, за результативного - постає розуміння, що формування могло початися раніше, триваючи й у 1141 році; дієприкметник була приєднана має лише акціональне значення. Рос. В 1918 году, когда город был занят немецкими войсками, я сам был исключен с «волчьим билетом» (В. Каверин). За акціонального розуміння конструкції был занят німці зайняли місто саме у 1918 році, за результативного окупація могла початися і раніше, триваючи й у 1918 році; між тим был исключен має лише перше, акціональне значення тощо. Вказівка на час для теперішнього результатива можлива для вираження повторюваної ознаки, хронологічної цикловості: укр. Школярські парти позбивано тепер гвіздками й клинцями (Б. Грінченко) - об'єкт стану (школярські парти) наділений повторюваною ознакою; рос.По праздничным дням 6 мастерской совсем пусто. На катке прибрано: колодочки и утюги задвинутые в угол, просечки, наперстки...сложены в ящик (В. Кузьмин) стан майстерні, який $\epsilon$ періодичним тощо. Вказівка на час для теперішнього результатива можлива також коли суб'єкт стану, результату повторюваної дії, є множинним: укр. Артисти всі ужже загримовані (А. Головко); рос. При них была и артиллерия, взятая Пугачевым в мальх крепостях, им уже покоренных (О. Пушкін) і таке інше. Для пасива таких обмежень немає: укр. Він ледве стримував себе від злості за те, щчо пришелепуватий Кукса своїм дурним пострілом так несподівано зірвав усю операцію. Тепер всі карти переплутано (В. Кучер) - однопланова, неповторювана дія (тепер переплутано = тепер переплутали) тощо.

На значення результативності / пасивності лексичної одиниці впливає також характер ii зв'язку 3 описуваними подіями. Лексема в пасивному значенні безпосередньо зумовлює подальший розвиток подій, постає їхнім прямим антецедентом: укр. Щойно ошукані Хомою $і$ тому особливо люті артилеристи з батогами накинулися на його коней (О. Гончар) - ошукав (антецедент) $\rightarrow$ накинулися (консеквент), отже, ๑ Ю. О. Голоцукова, 2015. 
ошукані - пасив; укр. Обидва вони були примічені королем $і$ тому підкреслено грузько сиділи в стильних кріселках (П. Панч) - примітив (антецедент) $\rightarrow$ сиділи (консеквент), отже, були примічені - пасив; рос. ... продавщица была предупреждена, что из горсовета может кое-кто нагрянуть в этот день. Поэтому она была очень осмотрительна ..., основательно высовывалась из ларька и смотрела направо и налево (Ф. Искандер) - попередили (антецедент) $\rightarrow$ була обачна (консеквент), отже, була попереджена - пасив тощо. За результативного значення лексема не передбачає якихось інших дій, ii зв'язок 3 тим, що відбувається, полягає лише у збереженні результативного стану: укр. Між нашим народом доволі й таких [пісень], де дівчина показується просто одуреною, ошуканою або й насильно зганьбленою (I. Франко) ошукана дівчина - результативний стан, отже, ошукана - результатив; рос. Долго я думал, куда же мне спрятать мое письмо. Я бросил его в щель столба, подпиравщего террасу. Столб был обшит досками. Три года спустя его нашел Петька Захаров (Вс. Иванов) - столб был обшит досками - результативний стан, отже, был обшит - результатив тощо.

О. Єсперсен, Ю. Маслов, О. Потебня та інші перфектом називають форму, що позначає дію в минулому, наслідки якої зберігаються в теперішньому. Ю. Маслов розмежував два типи перфекта - експліцитний та імпліцитний. 3 урахуванням засобів формального вираження експліцитний перфект виявний дієприкметниковими формами та предикативними формами на -но, -mo. Імпліцитний перфект репрезентований особовими формами. Перфектного значення набувають конструкції у поєднанні: 1) з обставинами часу на кшталт за дві години, за три роки, закілька днів і подібне: укр. Вже спалахнув над чохлом n'ятипромінний вогник золотого вінчика, пригрів собою сердитого, вимотаного за день Самієва (О. Гончар); рос. И на сем-то странном военном совете за минуту решено было идти к Оренбургу: движение дерзкое, и которое чуть было не увенчалось бедственным успехом! (О. Пушкін) та інше; 2) з обставинами, що фіксують відрізок минулого як час здійснення дії: укр. $A$ влімку ще ци свіжою рогозою долівку настелено (О. Гончар); рос. Во всяком случае, у него положено было еще прошлою весной, в скором времени, отлично и с достатком выдать Настасью Филипповну замуж за какого-нибудь благоразумного и порядочного господина, служащего в другой губернии (Ф. Достоєвський) і подібне; 3) 3 обставинами місця, оскільки вони позначають просторовий вимір перебігу тієї чи тієї дії: укр. Хапаючись за виліплені на стіні узори, ступив [Сашко] кілька кроків по коридору (Л. Смілянський); рос. По двору скакали конные 
люди; в эту минуту в узкое отверстие, прорубленное в стене, просунулась седая голова Савельича, и мой бедный дядька произнес жалобным голосом... (О. Пушкін) і таке інше; 4) з обставинами способу дії, що вказують на характер протікання дії: укр. Потім, повільно відігріті, знову розмерзають, відживають і починають жити (І. Смолич); рос. $B$ первой же комнате ждала и Настасья Филипповна, тоже одетая весьма просто и вся в черном; она встала навстречу, но не ульюнулась и даже князю не подала руки (Ф. Достоєвський) і таке інше; 5) з обставинами мети дії, підрядними мети, певного цільового спрямування дії: укр. - Треба перевірити Яська, вставив я своє слово, - Може, він Борисом засланий до нас, щцоб пронюхувати (М. Чабанівський); рос. Доктор, приглашенный для осмотра разбитой головы, дал примочку и объявил, что опасности от ушибов нет ни малейшей (Ф. Достоєвський) та інше; 6) 3 граматично обов'язковим запереченням. Граматична факультативність заперечення - свідчення результативності конструкції: укр. Коло дому бовваніли височезні осокори, зеленів старий садок, не одгороджений од двору (І. Нечуй-Левицький) тощо. Обов'язковість заперечення - показник перфектної семантики конструкції. Мотивацію обов'язковості можна вбачати також у поєднанні заперечної частки не з часткою ще, що свідчить про тривалу дію: укр. Може б, несподівано метнутись до клуні, припасти до току, де лежить ще не млинковане зерно, або скочити взасторонок з сіном? (М. Стельмах); рос. Наш отпрыск, назад тому с полгода, обутый в итиблеты поиностранному и дрожа в ничем не подбитой шинелишке, воротился зимой в Россию из Швейцарии, где лечился от идиотизма (Ф. Достоєвський) i подібне. Зазначені конструкції набувають саме перфектного значення, оскільки вказують на період, заповнений виконаною дією.

Лексеми, виражені пасивними дієприкметниками та акціональними предикативними формами на -но, -то від граничних і неграничних перфективів, що залежно від контексту можуть набувати результативного, пасивного чи стативного значення, називаємо контекстуально зумовленими результативами.

Отже, на відміну від статива, результатив української та російської мов повідомляє одночасно і про стан, і про попередню дію, результатом якої $\epsilon$ цей стан. Форми пасива $\epsilon$ омонімічними формам результатива в досліджуваних мовах. Частотними постають випадки, коли результатив і пасив допускають взаємозамінність у певних контекстах за незначної смислової зміни. На відміну від перфектного результативне значення не реалізується у поєднанні з обставинами часу, місця, способу дії, мети дії, 3 граматично обов'язковим запереченням тощо, оскільки такі конструкції ๑ Ю. О. Голоцукова, 2015. 
вказують на період, заповнений виконанням дії, а не результативним станом. На відміну від російської мови, українські конструкції з показниками тривалості зразка укр. у роки моєї молодості, взимку, навесні тощо реалізують пасивне значення лексеми, позначаючи час самої дії. У російські мові такі конструкції репрезентують лише результативний стан.

Аналізуючи співвідношення результатива 3 лексико-граматичною семантикою стативності, пасивності та перфектності в українській та російській мовах, можемо говорити про універсальний характер категорії результатива, певні відмінності в репрезентації категорії результатива можуть бути пояснені безперервним розвитком досліджуваних мов. Проблема категорії результатива, не зважаючи на тривалу історію іiі вивчення, залишається однією з дискусійних.

\section{Література}

1. Єсперсен О. Философия грамматики. / Отто Єсперсен ; [пер. сангл. Б. И. Ильиш]. - [2-е изд., стереотип.]. - М. : Едиториал УРСС, 2002. - 408 с.

2. Маслов Ю. С. Результатив, перфект и глагольный вид / Ю. С. Маслов // Типология результативных конструкций. - Л. : Наука, 1983. - С. 41-54.

3. Недялков В. П. Типология результативных конструкций: результатов, статив, пассив, перфект / В. П. Недялков, С. Е. Яхонтов - Л., 1983. - 263 с.

4. Потебня А. А. Из записок по русской грамматике : в 4-х т. / А. А. Потебня. М. : Просвещение, 1968. - Т. 4. -552 с.

5. Холодович А. А. О предельных и непредельных глаголах : (по данным корейского и японского языков) / А. А. Холодович // Филология стран Востока. - Л., 1963.- С. 3-11.

6. Холодович А. А. Проблемы грамматической теории / А. А. Холодович - Л., 1979. $-304 \mathrm{c}$.

7. Храковский В. С. Типология пассивных конструкций. Диатезы и залоги / В. С. Храковский, С. Е. Яхонтов, Г. Г. Сильницкий и др. ; ред. А. А. Холодович. - Л. : Наука, 1974. - 380 c.

8. Храковский В. С. Некоторые проблемы универсально-типологической характеристики аспектуальных значений / В. С. Храковский // Аспектуальность и средства ее выражения : Уч. зап. Тартуск. гос. ун-та. 1980. - Т. 537. - С. 3-23.

9. Чуглов В. И. Категории залога и времени у русских причастий / В. И. Чуглов // Вопросы языкознания. - 1990. - № 3. - С. 54-61.

10. Шелякин М. А. Категория вида и способа действия: (теоретические основы) / М. А. Шелякин - Таллин, 1983. - 216 с.

11. Wierzbicka A. Lingua Mentalis : the Semantics of Natural Language / A. Wierzbicka. - Sydney, 1980. -367 p.

12. Wierzbicka A. On the Semantics of the Verbal Aspect in Polish / A. Wierzbicka // To Honor Roman Jakobson. Essays on the Occasion of his Seventieth Birthday - The Hague - Paris, 1967. - P. 2231-2243.

13. Wieczorek D. Ukrainskij pierfekt na -no, -to na fonie polskogo pierfekta / 
D. Wieczorek. - Wrocław : Wydavnictwo Uniwersytetu Wrocławskiego 1994. - $115 \mathrm{~s}$.

Стаття надійшла до редакиії 02.09.2015 p. 